\title{
ANALISA KRONOLOGIS PERMASALAHAN BATAS WILAYAH ADMINISTRASI KABUPATEN DONGGALA DAN KABUPATEN MAMUJU UTARA DENGAN MENGGUNAKAN METODE KARTOMETRIK DAN GEOSPASIAL
}

\author{
Yuwono $^{1}$, Yanto Budisusanto ${ }^{2}$, Zahratu Firdaus ${ }^{3}$ \\ 1,2,3 Departemen Teknik Geomatika, FTSLK-ITS, Kampus ITS Sukolilo, Surabaya, 60111, Indonesia \\ e-mail: ${ }^{1}$ yuwono@geodesi.its.ac.id
}

\begin{abstract}
Abstrak
Sejak implementasi otonomi daerah yang luas, nyata dan bertanggung jawab berdasarkan UU No. 22 Tahun 1999 tentang Pemerintahan Daerah yang kemudian diganti UU No. 32 Tahun 2004 dan yang paling terbaru UU No. 23 Tahun 2014, batas antar daerah menjadi perhatian yang sangat penting. Dalam era otonomi daerah, banyak sekali perkembangan daerah baik desa, kabupaten/kota maupun provinsi yang mengadakan pemekaran. Pemekaran mengakibatkan adanya perebutan lahan atau sengketa lahan. Satu diantaranya yaitu batas wilayah antara Kabupaten Donggala dan Kabupaten Mamuju Utara. Konflik batas daerah Kabupaten Donggala dan Kabupaten Mamuju Utara ini muncul sebagai akibat dari adanya kebijakan penataan batas daerah berdasarkan Kepmendagri No. 52 Tahun 1991 terutama setelah pemasangan Tugu / Patok Batas pada kawasan perbatasan antara Kabupaten Donggala dengan Kabupaten Mamuju Utara yang kurang melibatkan masyarakat setempat. Tujuan dari penelitian ini adalah untuk menganalisa permasalahan batas wilayah yang terjadi pada Kabupaten Donggala dan Kabupaten Mamuju Utara berdasarkan data historis kedua Kabupaten tersebut serta mengimplementasikan Permendagri No. 76 Tahun 2012 tentang Penegasan Batas Daerah. Metode yang digunakan dalam penelitian ini yaitu metode kartometrik serta kajian literatur terkait berbagai aspek menggunakan perangkat lunak SIG. Hasil analisa diketahui bahwa daerah yang diklaim atau Desa Ngovi lebih memilih untuk berada pada Kabupaten Donggala Provinsi Sulawesi Tengah, namun jika dilihat dari segi hukum yang berlaku, daerah klaim tersebut tetap berada pada wilayah Kabupaten Mamuju Utara Provinsi Sulawesi Barat. Luas wilayah yang diperebutkan sebesar 4696.469 ha, dimana wilayah tersebut terdapat penduduk dan bangunan pemerintah.
\end{abstract}

Kata Kunci : Batas Wilayah, Data Historis, Peta Alternatif.

\begin{abstract}
Since the implementation of broad regional autonomy, real and responsible based on Law no. 22 of 1999 on Regional Government which was then replaced by Law no. 32 of 2004 and the most recent Law no. 23 Year 2014, boundaries between regions become a very important concern. In the era of regional autonomy, there are a lot of regional developments in the villages, districts / municipalities and provinces that have split up. Due to the existence of the division is adaya seizure of land or land disputes. One of them is the boundary between Donggala and North Mamuju. The boundary conflicts of Donggala and North Mamuju districts have emerged as a result of regional border policy policy based on Kepmendagri no. 52 Year 1991, especially after the installation of Tugu / Patok Batas in the border area between Donggala District and North Mamuju Regency which less involving the local community. The purpose of this study is to analyze the boundary problems that occurred in Donggala and North Mamuju regencies based on historical data of the two districts and the implementation of Permendagri no. 76 Year 2012 on Regional Boundary Affirmation. The method used in this research is cartometric method and literature study related to various aspects using GIS software. The result of analysis is known that claimed area or Ngovi Village prefer to be in Donggala Regency Central Sulawesi Province, but if viewed from law aspect, area of claim remain in region of Regency of North Mamuju West Sulawesi Province. The total area of the contested area is 4696,469 ha, of which there are residents and government buildings.
\end{abstract}

Keywords : Borders, Historical Data, Alternative Map. 


\section{PENDAHULUAN}

Sejak implementasi otonomi daerah yang luas, nyata dan bertanggung jawab berdasarkan UU No. 22 Tahun 1999 tentang Pemerintahan Daerah yang kemudian diganti UU No. 32 Tahun 2004 dan yang paling terbaru UU No. 23 Tahun 2014, batas antar daerah menjadi perhatian yang sangat penting. Dalam era otonomi daerah, banyak sekali perkembangan daerah baik desa, kabupaten/kota maupun provinsi yang mengadakan pemekaran. Hal ini mengakibatkan timbulnya potensi konflik antar daerah bahkan juga menimbulkan dampak politis di daerah perbatasan. Dalam pelaksanaannya, banyak pemerintah daerah mengalami kesulitan menata batas wilayah (Joyosumarto 2013).

Aspek wilayah menjadi hal yang sangat penting sebab wilayah suatu daerah mencerminkan sejauh mana kewenangan daerah tersebut dapat dilaksanakan. Pasca penerapan otonomi daerah, permasalahan yang sering muncul baik antar daerah otonom maupun dalam satu daerah otonom adalah permasalahan batas wilayah. Satu diantaranya yaitu batas wilayah antara Kabupaten Donggala dan Kabupaten Mamuju Utara.

Penelitian ini bertujuan untuk menganalisa kronologis permasalahan sengketa Kabupaten Donggala dan Kabupaten Mamuju Utara berdasarkan data historis yang ada. Analisa tersebut nantinya akan digunakan sebagai acuan dalam pembuatan peta alternatif batas wilayah Kabupaten Donggala dan Kabupaten Mamuju Utara yang dijadikan perbandingan oleh peta batas sebelumnya. Penarikan garis batas berdasarkan Peraturan Menteri Dalam Negeri No. 76 Tahun 2012 tentang Pedoman Penegasan Batas Daerah. Metode yang digunakan dalam penelitian ini yaitu metode kartometrik dan kajian literatur terkait permasalahan kedua Kabupaten tersebut.

Metode Kartometrik adalah penarikan garis batas pada peta kerja dan pengukuran/penghitungan posisi titik, jarak serta luas cakupan wilayah dengan menggunakan peta dasar dan peta-peta lain sebagai pelengkap (Kementerian Dalam Negeri 2012).

\section{METODOLOGI PENELITIAN}

\section{Lokasi Penelitian}

Lokasi penelitian ini dilakukan di Kabupaten Donggala, Provinsi Sulawesi Tengah dengan koordinat $0^{\circ} 40^{\prime} 42^{\prime \prime} \mathrm{LU}-2^{\circ} 30^{\prime} 20^{\prime \prime}$ LS serta $119^{\circ} 45^{\prime}$ 9" $-121^{\circ} 45^{\prime} 24^{\prime \prime}$ BT dan Kabupaten Mamuju Utara, Provinsi Sulawesi Barat dengan koordinat $0^{\circ} 40^{\prime} 10^{\prime \prime}$ - $1^{0} 50^{\prime} 12^{\prime \prime}$ LS dan $119^{\circ} 25^{\prime} 26^{\prime \prime}-119^{\circ} 50^{\prime} 20^{\prime \prime}$ BT.

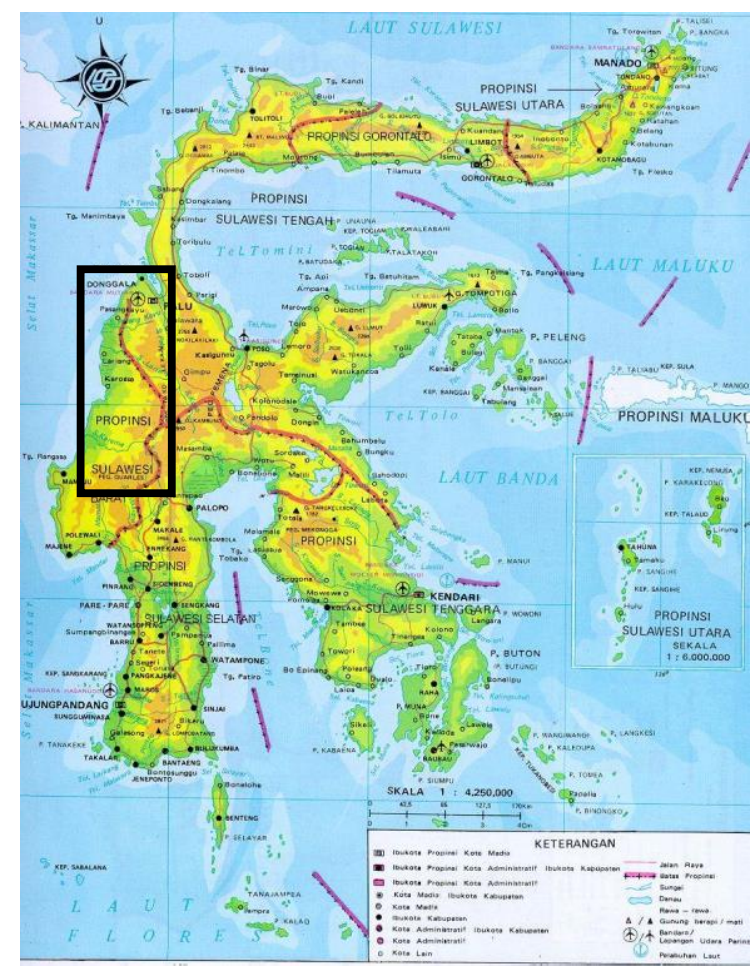

Gambar 1. Lokasi Penelitian

(Sumber : mappery 2009)

\section{Data dan Peralatan}

a. Data

Data yang digunakan dalam penelitian ini yaitu meliputi berikut:

1. Peta RBI digital batas wilayah Kabupaten Donggala dan Kabupaten Mamuju Utara skala 1:50000 tahun 2016

2. Citra satelit resolusi tinggi SPOT-7 (Satellite Pour l'Observtion de la Terre - 7) tahun 2014/2015 dengan skala 1:25000

3. Data garis batas menurut Permendagri No. 76 tahun 2012 
4. Data historis seperti data pembentukkan Kabupaten Donggala dan Kabupaten Mamuju Utara, data administrasi, data toponimi, dan data geografis.

\section{b. Peralatan}

Peralatan yang digunakan dalam penelitian ini adalah Perangkat Lunak (Sofware) yaitu:

1. Windows 10

2. Perangkat lunak pengolah kata dan angka

3. Perangkat lunak SIG (Sistem Informasi Geografis)

\section{Tahap Pengolahan Data}

Adapun diagram alir yang menjelaskan proses analisa garis batas wilayah dari penelitian ini dapat dejelaskan pada Gambar 2 seperti di bawah ini.

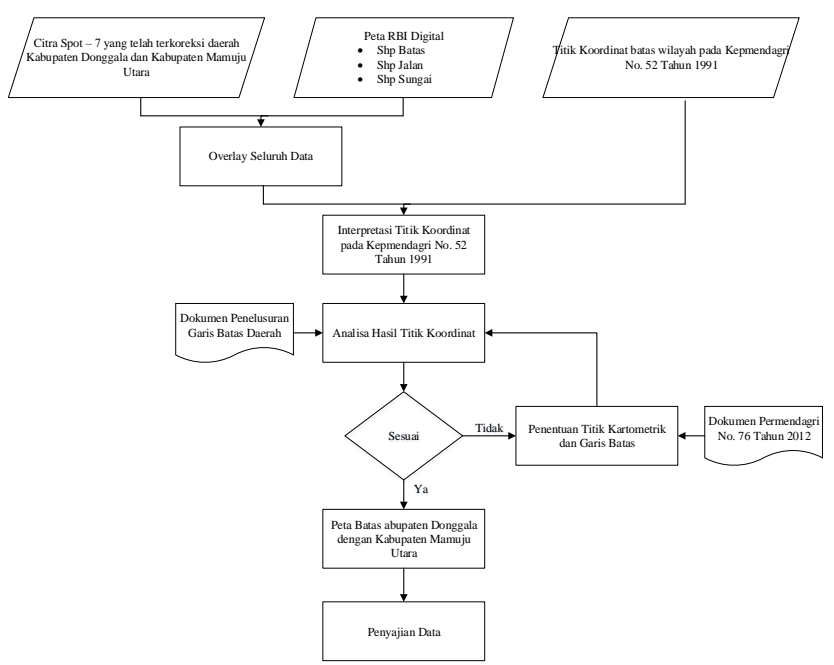

Gambar 2. Diagram Alir Penelitian

Setelah semua data yang dibutuhkan telah terkumpul selanjutnya dari Gambar 2 di atas dapat dijelaskan proses pengolahan data pada penelitian ini adalah sebagai berikut.

1. Overlay Data

Data yang telah terkumpul di tampalkan atau di overlay untuk menyamakan tampilan antara citra dengan peta RBI. Overlay yaitu menampalkan suatu peta digital pada peta digital yang lain beserta atribut-atributnya dan menghasilkan peta gabungan keduanya yang memiliki informasi atribut dari kedua peta tersebut

2. Analisa Garis Batas Wilayah

Dari hasil overlay tersebut, selanjutnya dilakukan analisa garis batas wilayah
Kabupaten Donggala dan Kabupaten Mamuju Utara (Permendagri 76/2012) dengan data historis yang ada pada kedua Kabupaten tersebut.

3. Penentuan Titik Kartometrik dan Penarikan Garis Batas

Pada tahap penetuan titik kartometrik dan penarikan garis batas didasarkan pada Peraturan Menteri Dalam Negeri No. 76 tahun 2012 tentang penegasan batas daerah.

4. Penyajian Data

Hasil akhir berupa peta alternatif garis batas antara Kabupaten Donggala dan Kabupaten Mamuju Utara menurut data historis serta perbandingan dengan peta alternatif garis batas menurut Permendagri No. 76 Tahun 2012.

\section{HASIL DAN PEMBAHASAN}

\section{Peta Alternatif menurut Permendagri No 76/2012}

Proses pembuatan peta alternatif menurut Permendagri No. 76/2012 dihasilkan dari pengumpulan data pendukung utama seperti peta RBI, citra spot-7, serta data Permendagri No. 76 Tahun 2012 yang diperbaharui dengan Permendagri No. 141 Tahun 2017. Pada penelitian ini peta alternatif dibagi menjadi 4 lembar peta berindeks. Gambar 3 menunjukkan hasil dari analisa sesuai peraturan yang ada saat ini.

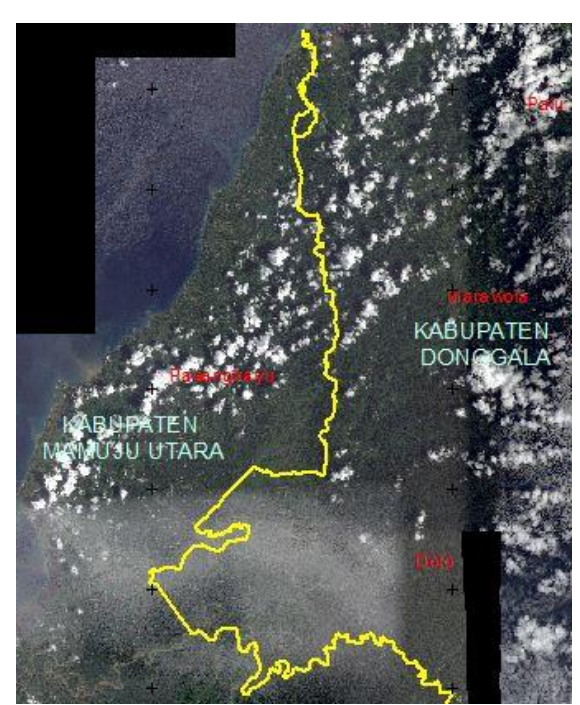

Gambar 3. Garis Batas Wilayah menurut Hukum 
Pada peta alternatif ini diketahui bahwa Desa Ngovi terletak pada Kabupaten Mamuju Utara Provinsi Sulawesi Barat, dilihat dari hasil analisa sesuai Permendagri No. 76 Tahun 2012 dan data koordinat Kepmendagri No. 52 Tahun 1991 yang menyatakan Desa Ngovi masuk kewilayah Kabupaten Mamuju Utara. Pada Permendagri No. 76 Tahun 2012 tentang penegasan batas daerah dijelaskan bahwa kaidah-kaidah penarikan garis batas secara kartometrik dilihat dari batas alam (sungai, pegunungan, dan danau) dan batas buatan (jalan). Berikut sampel penarikan garis batas,

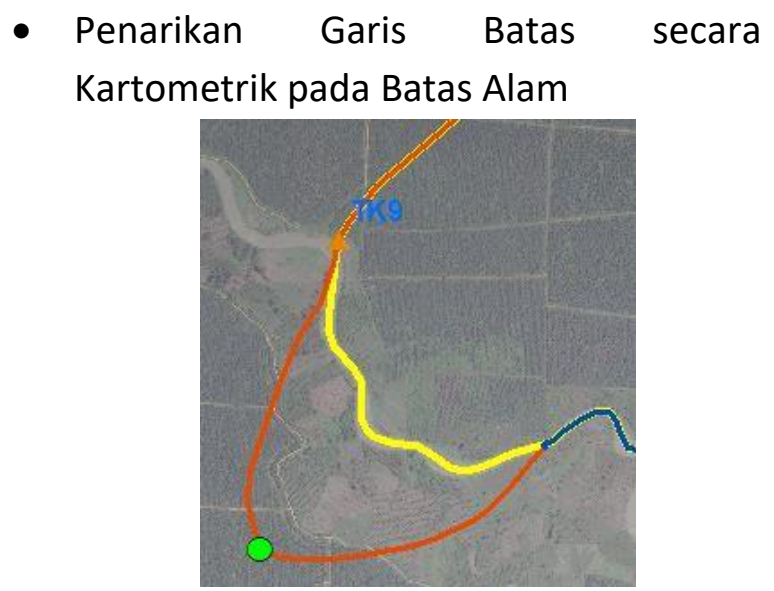

Gambar 4. Sampel Penarikan Garis Batas Alam

- Penarikan Garis Batas secara Kartometrik pada Batas Buatan

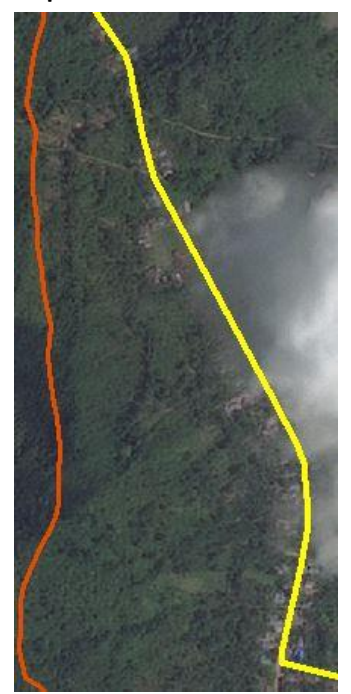

Gambar 5. Sampel Penarikan Garis Batas Buatan

Gambar 4 menunjukkan garis merah adalah garis batas dari Kepmendagri sedangkan garis kuning adalah garis batas yang diperbaiki atau ditarik menggunakan metode kartometrik sesuai Permendagri 76/2012. Sumber data penarikan garis tersebut yaitu Citra Spot-7 dan peta RBI digital. Lokasi penarikan garis batas alam sesuai Permendagri 76/2012 ada pada beberapa tempat yaitu, Desa Martasari, Desa Kasoloang, Desa Randomayang, Desa Martajaya, dan Desa Sarjo.

Penarikan garis batas yang ditunjukkan pada gambar 5 adalah garis batas buatan (jalan) yang diberi warna kuning, sedangkan warna merah adalah garis batas Kepemendagri. Penarikan garis buatan pada penelitian ini menggunakan sumber data Citra Spot-7. Adapun lokasi-lokasi garis batas buatan yaitu, Desa Bambalamotu, Desa Plewali, Desa Sarjo, Desa Malino, dan Desa Tikke.

\section{Peta Alternatif menurut Data Historis Donggala}

Peta alternatif menurut data historis Kabupaten Donggala dibuat dengan data dasar berupa beberapa aspek pendukung penyelesaian batas wilayah serta data garis batas wilayah Desa Ngovi menurut Kabupaten Donggala. Adapun hasil analisa dari aspek-aspek pendukung penyelesaian batas wilayah yaitu,

- Aspek Hukum

Keputusan Menteri Dalam Negeri (Kepmendagri) No. 52 Tahun 1991 tentang penegasan garis batas wilayah antara Provinsi daerah tingkat I Sulawesi Selatan dengan Provinsi daerah tingkat I Sulawesi Tengah.

- Aspek Administrasi

Penduduk Desa Ngovi sebagian besar memiliki kartu tanda penduduk (KTP) di wilayah Kabupaten Donggala Provinsi Sulawesi Tegah.

- Aspek Toponimi

Peraturan Menteri Dalam Negeri No. 131 Tahun 2017 tentang Kode dan Data Wilayah Administrasi Pemerintahan, dalam lampirannya menjelaskan bahwa wilayah Desa Ngovi masuk ke wilayah Kecamatan Rio Pakava, Kabupaten Donggala Provinsi Sulawesi Tengah. 
- Aspek Geografis

Jarak atau jalur akses Desa Ngovi ke kantor administrasi pemerintah Kabupaten Donggala kurang lebih 79 km. Sedangkan jarak dari Kabupaten Mamuju Utara kurang lebih $30 \mathrm{~km}$ dari kantor administrasi pemerintahan.

Dari keempat aspek diatas, dapat disimpulkan bahwa secara data historis Desa Ngovi terletak pada wilayah Kabupaten Donggala, sesuai dengan data pendukung garis batas menurut masyarakat Kabupaten Donggala pada gambar 6 .

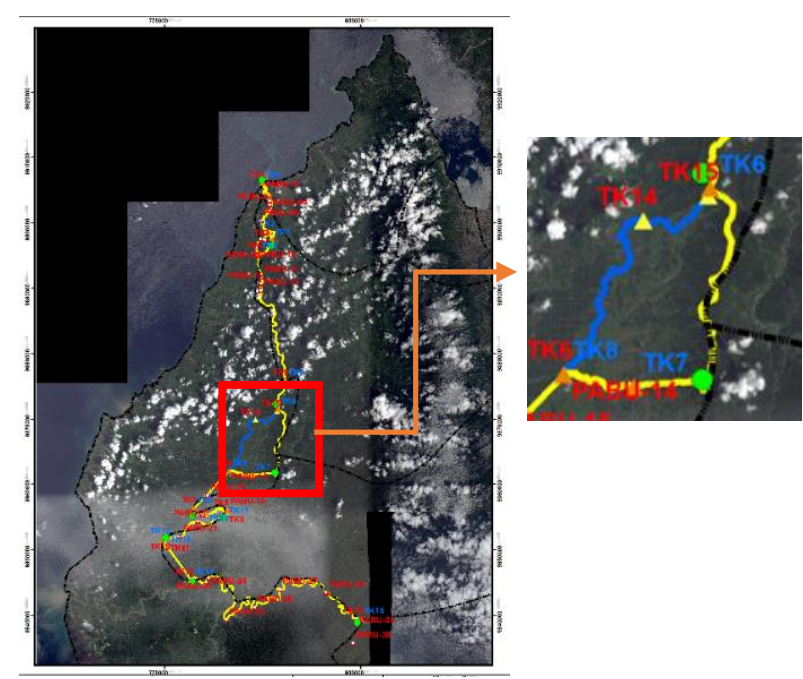

Gambar 6, Garis Batas Desa Ngovi

\section{Hasil Titik Kartometrik}

Setelah ditentukan garis batas wilayahnya, selanjutnya penempatan titik kartometrik yang tersebar pada garis batas wilayah Kabupaten Donggala dan Kabupaten Mamuju Utara. Penomoran titik kartometrik dan informasi koordinat setiap titik kartometrik pada penelitian ini dapat dilihat pada table 1.

Sesuai Peraturan Menteri Dalam Negeri No. 45 Tahun 2016 Tentang Pedoman Penetapan dan Penegasan Batas Desa untuk penomoran titik kartometrik adalah sebagai berkut:

1) Desa dalam satu kecamatan:

TK11.01.01.2001-01.2002-001

\begin{tabular}{|c|c|c|c|c|c|c|c|}
\hline TK & 11 & 01 & 01 & 2001 & 01 & 2002 & 001 \\
\hline $\begin{array}{l}\text { 2) } \\
\mathrm{TK} 11\end{array}$ & \multicolumn{7}{|c|}{$\begin{array}{l}\text { Desa/kelurahan berbeda kecamatan: } \\
1.01 .2001-02.1005-001\end{array}$} \\
\hline TK & 11 & 01 & 01 & 2001 & 02 & 1005 & 001 \\
\hline
\end{tabular}

Keterangan:

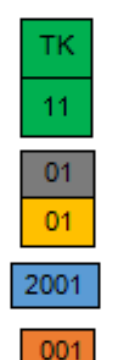

001

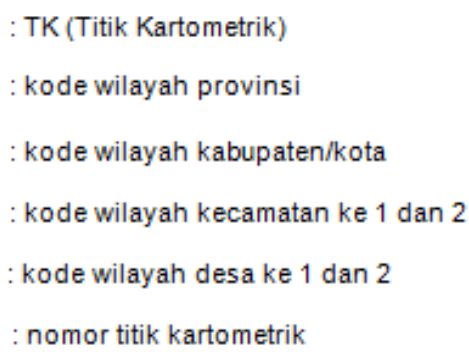

Tabel 1. Koordinat Titik Kartometrik

\begin{tabular}{|c|c|c|c|}
\hline \multirow{2}{*}{ NO } & \multirow{2}{*}{ TITIK KARTOMETRIK } & \multicolumn{2}{|c|}{ KOORDINAT } \\
\hline & & $X(m)$ & $\mathrm{Y}(\mathrm{m})$ \\
\hline 1 & $\begin{array}{c}\text { TK76.01.11.2001- } \\
02.11 .2007-001\end{array}$ & 785041.264 & 9906091.759 \\
\hline 2 & TK76.01.11.2001- & & \\
\hline \multirow[t]{2}{*}{3} & $\begin{array}{c}\text { 02.11.2007-002 } \\
\text { TK76.01.11.2001- }\end{array}$ & 785837.689 & 9898625.748 \\
\hline & 02.11.2007-003 & 786429.141 & 9897332.586 \\
\hline \multirow{2}{*}{4} & TK76.01.11.2001- & & \\
\hline & 01.1006-004 & 784392.869 & 9895363.463 \\
\hline \multirow{2}{*}{5} & TK76.01.11.2001- & & \\
\hline & 01.1006-005 & 788469.785 & 9875887.753 \\
\hline \multirow{2}{*}{6} & TK76.01.01.2003- & & \\
\hline & 02.1002-006 & 787288.105 & 9871534.139 \\
\hline \multirow[t]{3}{*}{7} & TK76.01.02.1002- & & \\
\hline & 09.2004-007 & 783408.946 & 9861422.739 \\
\hline & TK76.01.02.1002- & & \\
\hline \multirow[t]{2}{*}{8} & 09.2004-02.1001- & & \\
\hline & 008 & 779862.080 & 9862054.213 \\
\hline \multirow[t]{2}{*}{9} & TK76.01.09.2004- & & \\
\hline & $\begin{array}{c}\text { 02.1001-009 } \\
\text { TK76.01.09.2004- }\end{array}$ & 774475.719 & 9856398.379 \\
\hline \multirow[t]{2}{*}{10} & TK72.03.04.2004- & & \\
\hline & 010 & 779682.738 & 9856001.485 \\
\hline \multirow{2}{*}{11} & TK76.01.09.2004- & & \\
\hline & 08.2001-011 & 779377.661 & 9854804.880 \\
\hline \multirow{2}{*}{12} & TK76.01.09.2004- & & \\
\hline & 08.2001-012 & 769705.178 & 9851666.709 \\
\hline \multirow{2}{*}{13} & TK76.01.09.2004- & & \\
\hline & 08.2001-013 & 770396.462 & 9850444.650 \\
\hline \multirow{2}{*}{14} & TK76.01.09.2004- & & \\
\hline & 08.2001-014 & 774004.318 & 9845443.654 \\
\hline \multirow{2}{*}{15} & TK76.01.08.2001- & & \\
\hline & 03.1001-015 & 800039.307 & 9839447.866 \\
\hline
\end{tabular}

\section{KESIMPULAN DAN SARAN}

Kesimpulan yang dapat diambil dari penelitian in adalah sebagai berikut:

1. Hasil dari analisa garis batas Kepmendagri No. 52 Tahun 1991 menurut Permendagri No. 76 Tahun 2012 dan data historis, terdapat beberapa koreksi garis batas diantaranya pada wilayah Desa Martasari, Desa Kasoloang, Desa Randomayang, Desa Martajaya, Desa Sarjo, 
Desa Bambalamotu, Desa Plewali, Desa Malino, dan Desa Tikke.

2. Dihasilkan analisa dari beberapa aspek permasalahan batas wilayah Kabupaten Donggala dan Kabupaten Mamuju Utara bahwa daerah sengketa atau Desa Ngovi berada pada Kabupaten Donggala Provinsi Sulawesi Tengah, namun jika dilihat dari segi hukum yang berlaku, daerah tersebut tetap berada pada wilayah Kabupaten Mamuju Utara Provinsi Sulawesi Barat sesuai Kepmendagri No. 52 Tahun 1991.

Saran untuk penelitian selanjutnya mengenai sengketa batas wilayah, sebaiknya menggunakan data acuan dengan akurasi tinggi, baik citra satelit (resolusi spasial sekitar 0.4 hingga $4 \mathrm{~m}$ ) maupun peta dasar, sehingga didapatkan batas wilayah yang lebih akurat sesuai dengan kondisi asli dilapangan. Permendagri No. 141 Tahun 2017 menyatakan skala minimal untuk peta batas wilayah Kabupaten yaitu 1:100000.

\section{DAFTAR PUSTAKA}

Joyosumarto, S. (2013). Sengketa Batas Daerah pada Era Otonomi Daerah di Indonesia. Yogyakarta: Program Pascasarjana S3 Teknik Geomatika Fakultas Teknik UGM. (http://www.wilayahperbatasan.com/sengket a-batas-daerah-pada-era-otonomi-daerah-diindonesia/).

Kementerian Dalam Negeri a. (2012). Peraturan Menteri Dalam Negeri Republik Indonesia No.76 Tahun 2012 Tentang Pedoman Penegasan Batas Daerah., Jakarta.

Kementerian Dalam Negeri. (2016). Lampiran Peraturan Menteri Dalam Negeri Republik Indonesia No.45 Tahun 2016 Tentang Pedoman Penetapan dan Penegasan Batas Desa, Jakarta. 


\section{LAMPIRAN}

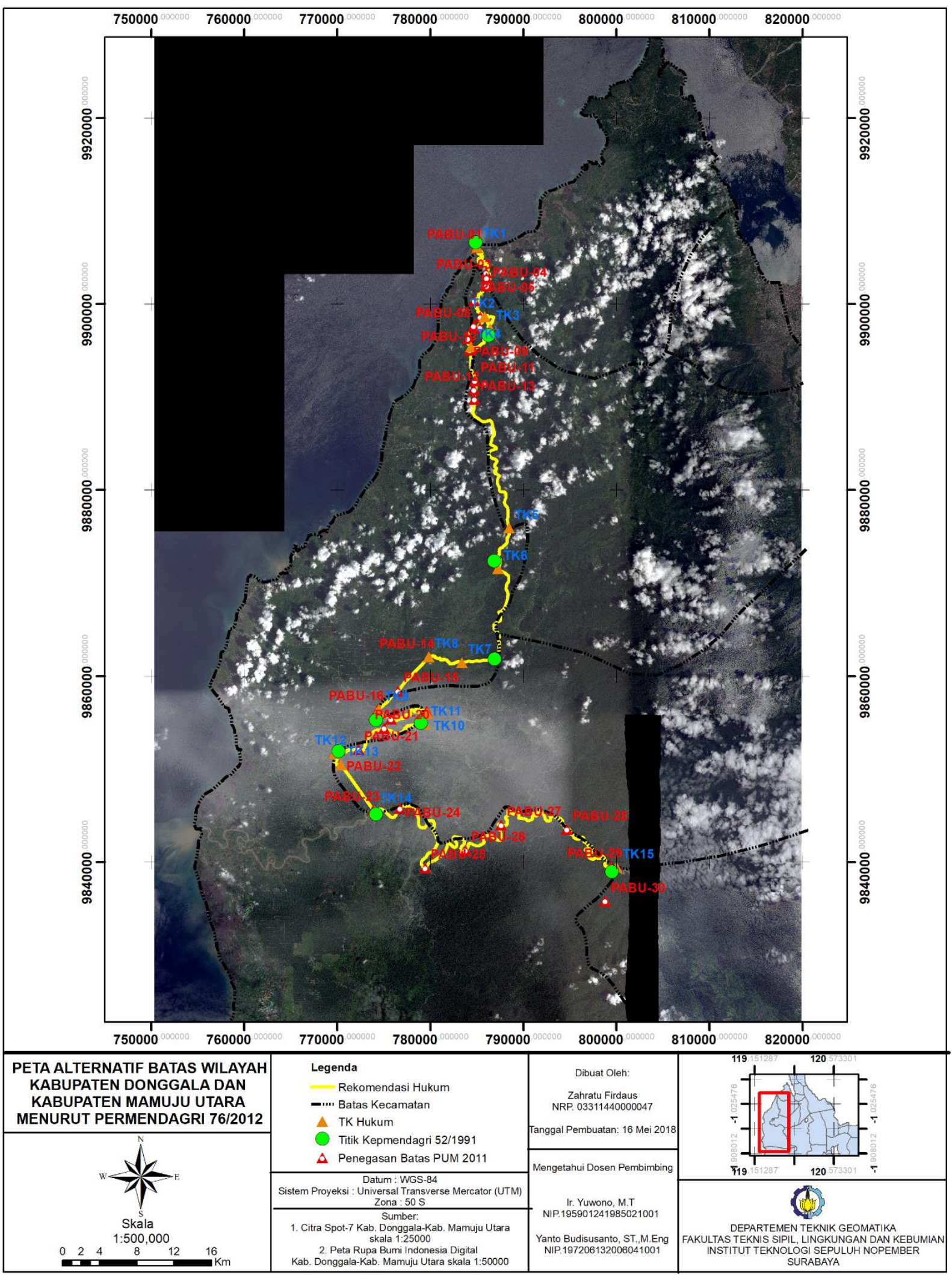




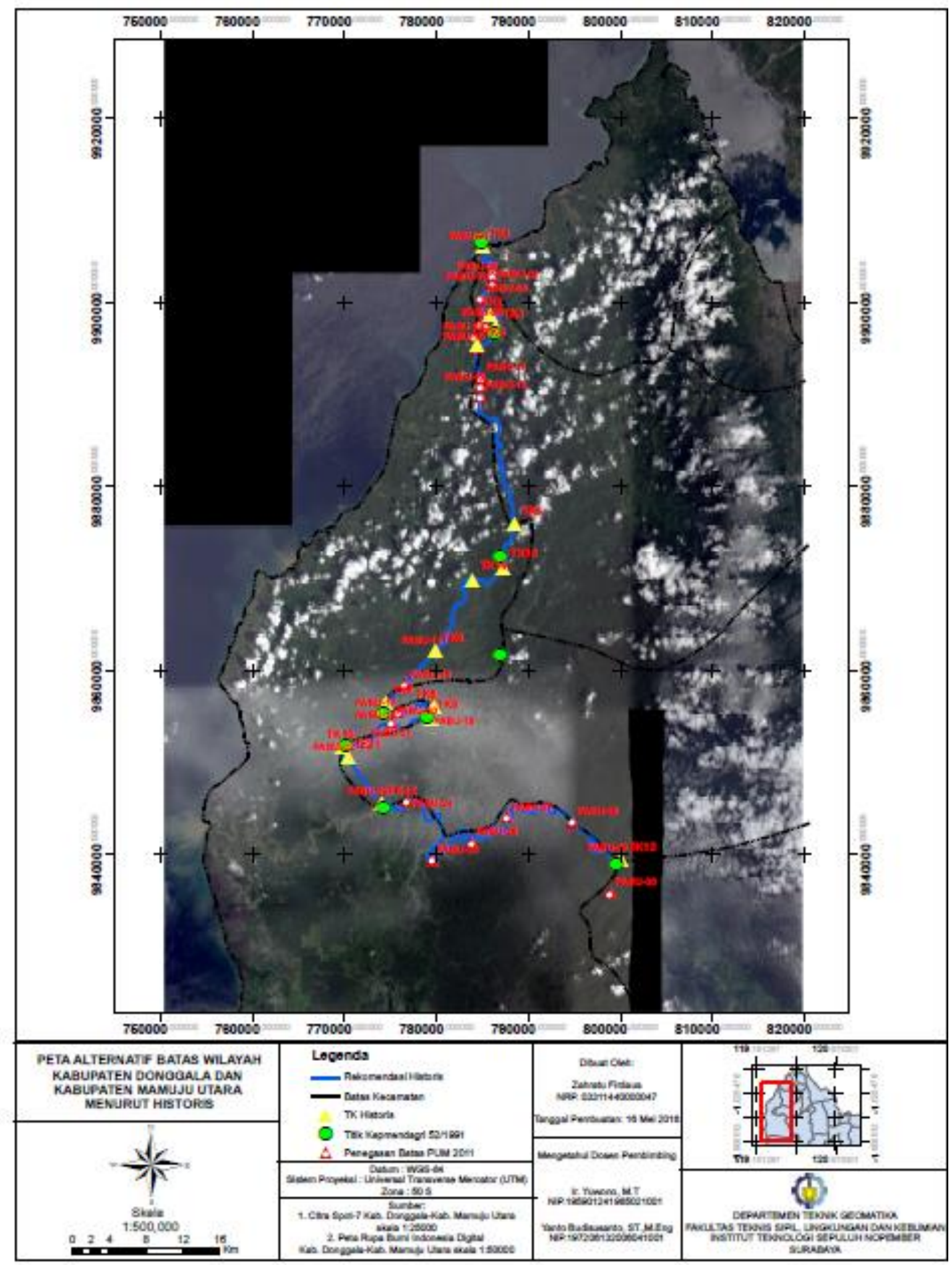

